\title{
Determination of Rare Earth Elements in Human Sperm and Association with Semen Quality
}

\author{
Urszula Marzec-Wróblewska ${ }^{1,2} \cdot$ Piotr Kamiński $^{2,3} \cdot$ Paweł Lakota $^{4} \cdot$ \\ Grzegorz Ludwikowski $^{5}$ - Marek Szymański ${ }^{6,7} \cdot$ Karolina Wasilow $^{7,8}$. \\ Tomasz Stuczyński ${ }^{9}$ Adam Buciński ${ }^{1} \cdot$ Leszek Jerzak $^{10}$
}

Received: 9 July 2014/ Accepted: 28 February 2015/Published online: 12 March 2015

(C) The Author(s) 2015. This article is published with open access at Springerlink.com

\begin{abstract}
The aim of the present study was to measure lanthanum $(\mathrm{La})$, cerium $(\mathrm{Ce})$, europium $(\mathrm{Eu})$, and gadolinium $(\mathrm{Gd})$ concentrations in human semen and correlate the results with sperm quality. The median semen content of La was $19.5 \mu \mathrm{g} \mathrm{kg}^{-1}$ dry weight (dw) (range 2.27-269), of Ce was $41.9 \mu \mathrm{g} \mathrm{kg}^{-1} \mathrm{dw}$ (range 4.52 to 167), of Eu was $0.68 \mu \mathrm{g} \mathrm{kg}^{-1} \mathrm{dw}$ (range 0.06-1.95), of $\mathrm{Gd}$ was $3.19 \mu \mathrm{g} \mathrm{kg}^{-1} \mathrm{dw}$ (range 0.38-12.0), and of calcium (Ca) was $4063 \mathrm{mg} \mathrm{kg}^{-1} \mathrm{dw}$ (range 484-17,191). Concentrations of $\mathrm{La}, \mathrm{Ce}, \mathrm{Eu}, \mathrm{Gd}$, and $\mathrm{Ca}$ were significantly lower in
\end{abstract}

Urszula Marzec-Wróblewska

u.marzec@cm.umk.pl

Piotr Kamiński

piotr.kaminski@cm.umk.pl; zeios@cm.umk.pl;

p.kaminski@wnb.uz.zgora.pl

Paweł Łakota

lakota@utp.edu.pl

Grzegorz Ludwikowski

ludwikowski.grzegorz@cm.umk.pl

Marek Szymański

kikpoloz@cm.umk.pl; szymar@hoga.pl

Karolina Wasilow

karolina.wasilow@gmail.com

Tomasz Stuczyński

ts@iung.pulawy.pl

Adam Buciński

kizbiofarmacji@cm.umk.pl

Leszek Jerzak

1.jerzak@wnb.uz.zgora.pl

1 Department of Biopharmacy, Faculty of Pharmacy,

Nicolaus Copernicus University in Toruń, Collegium

Medicum in Bydgoszcz, dr. A. Jurasz St. 2,

85-089 Bydgoszcz, Poland nondrinkers' semen than in semen from drinkers. Significant differences were detected between $\mathrm{La}, \mathrm{Ce}, \mathrm{Eu}, \mathrm{Gd}$, and $\mathrm{Ca}$ concentrations in semen from nondrinkers and moderate drinkers. Concentrations of $\mathrm{La}, \mathrm{Ce}$, and $\mathrm{Gd}$ in semen of short-term smokers were significantly lower than those in extremely long-term smokers. Significant differences were also detected between La concentration in semen from a group of short-term smokers and that of a group of long-term smokers. Positive correlations were found between $\mathrm{La}, \mathrm{Ce}, \mathrm{Eu}, \mathrm{Gd}$, and $\mathrm{Ca}$ concentrations in
2 Department of Ecology and Environmental Protection, Faculty of Medicine, Nicolaus Copernicus University in Toruń, Collegium Medicum in Bydgoszcz, M. SkłodowskaCurie St. 9, 85-094 Bydgoszcz, Poland

3 Department of Biotechnology, Faculty of Biological Sciences, University of Zielona Góra, Prof. Szafran St. 1, 65-516 Zielona Gora, Poland

4 Department of Animal Biotechnology, Faculty of Animal Biology, University of Technology and Life Sciences, Mazowiecka St. 28, 85-084 Bydgoszcz, Poland

5 Department of Clinical Andrology, Faculty of Medicine, University Hospital No. 2, Nicolaus Copernicus University in Toruń, Collegium Medicum in Bydgoszcz, Szpitalna St. 19, 85-092 Bydgoszcz, Poland

6 Department of Obstetrics, Female Pathology and Oncological Gynecology, University Hospital No. 2, Nicolaus Copernicus University in Toruń, Collegium Medicum in Bydgoszcz, Ujejski St. 75, 85-168 Bydgoszcz, Poland

7 NZOZ Medical Center Co. Prof. dr. hab. med. Wiesław Szymański, Dr. med. Marek Szymański, Waleniowa St. 24, 85-435 Bydgoszcz, Poland

8 Family Medicine Clinic, University Hospital No. 2, Nicolaus Copernicus University in Torun, Collegium Medicum in Bydgoszcz, Ujejski St. 75, 85-168 Bydgoszcz, Poland 
semen. $\mathrm{La}, \mathrm{Ce}, \mathrm{Gd}$, and $\mathrm{Ca}$ concentrations in semen were positively associated with progressive motility and percentage of normal spermatozoa. Positive correlations were found between $\mathrm{Ca}$ and sperm concentration. Concentrations of $\mathrm{La}, \mathrm{Ce}$, and $\mathrm{Gd}$ were negatively associated with sperm concentration, whilst $\mathrm{Ca}$ concentration was negatively associated with volume of ejaculate. At the examined level, $\mathrm{La}, \mathrm{Ce}, \mathrm{Eu}$, and Gd did not affect sperm quality, whereas alcohol consumption and smoking might have increased the level of rare earth elements in semen.

Rare earth elements (REEs) include 17 chemically similar metallic elements: 15 lanthanides plus scandium and yttrium. The elements lanthanum (La), cerium $(\mathrm{Ce})$, europium (Eu), and gadolinium (Gd) belong to this group. During the past few years, the widespread application of rare earth elements has been extensively reported in various fields including agriculture, animal husbandry, electronics, energy, fuel additives, and modern biomedicine. Rare earth ions initially enter organs; after transforming into metastable hydrogen oxide particles, they selectively accumulate in the liver and other reticular structures. This leads to enrichment of REEs in these tissues (Eisele et al. 1980; Nakamura et al. 1997; Chen et al. 2000; Kawagoe et al. 2008; Huang et al. 2011). It is well-known that REEs cause hepatotoxic and neurotoxic effects and lung damage (Basu et al. 1982; Porru et al. 2001; Feng et al. 2006, 2007; Palasz and Czekaj 2000; Kobayashi et al. 2005; Yang et al. 2009). La carbonate has been approved as a medicine for treating renal failure (Yamada et al. 2012), whereas Ce compounds are used for the treatment of severe skin burns and in antioxidant therapy, neuroprotection, radioprotection, and ocular protection (Monafo et al. 1976; Rzigalinski et al. 2006; Korsvik et al. 2007). Several investigators have shown that trivalent lanthanide ions may substitute calcium (Ca) at metal-binding sites in many proteins (Brittain et al. 1976; Martin and Richardson 1979) and membranes (Mikkelson 1976; dos Remedios 1981), whilst Ca is essential for sperm motility (Morton et al. 1974; Tash and Mean 1982; Hong et al. 1984; Fakih et al. 1986; Lindemann et al. 1987; Sørensen et al. 1999; Darszon et al. 2005), metabolic functions (Yanagimachi 1981), and acrosome reaction and fertilization (Yanagimachi and Usui 1974; Yanagimachi 1981; Hong et al. 1984; Sørensen et al. 1999). Only a few examples of REEs affecting semen motility are reported in the literature. Lee et al. (1981)

9 Department of Soil Structure, Institute of Agriculture and Soil Cultivation, Czartoryskich St. 8, 24-100 Puławy, Poland

10 Department of Nature Protection, Faculty of Biological Sciences, University of Zielona Góra, Prof. Szafran St. 1, 65-516 Zielona Gora, Poland showed that $\mathrm{La}^{3+}$ and $\mathrm{Eu}^{3+}$ inhibited motility stimulation in the presence of $\mathrm{Ca}$, whereas Saling (1982) showed that sperm immotility in the presence of $\mathrm{La}^{3+}$ can be reversed immediately by incubation with $\mathrm{Ca}^{2+}$. In addition, Oral et al. (2010) found that both $\mathrm{Ce}^{4+}$ and $\mathrm{La}^{3+}$ caused a decrease in sperm fertilization rate at a concentration of $10^{-5} \mathrm{M}$. The REE-related health impacts are still not fully elucidated, and systemic and basic information is still lacking (He and Rambeck 2000; Yu et al. 2007; He et al. 2008, 2010; Yang et al. 2009).

Nearly $40 \%$ of infertility cases are caused by male factor (Vayena et al. 2002); however, most of them are due to the inferior quality or the small quantity of spermatozoa. The rapid development and widespread application of novel REEs technologies in industrialized countries requires additional information on the potential health effects derived from possible exposure to REEs and their compounds. A review of the literature revealed that there is little information regarding the possible impact of REEs on human health, and - to the best of our knowledge - the contents of rare earth elements in human semen have not been determined. Thus, the aim of present study was to first measure $\mathrm{La}, \mathrm{Ce}, \mathrm{Ce}$, and $\mathrm{Ga}$ concentrations in human semen and, second, to correlate the results with sperm quality, total semen concentration of $\mathrm{Ca}$, and lifestyle habits.

\section{Materials and Methods}

\section{Human Semen}

Semen samples were received from male partners of infertile couples $(N=168)$ undergoing routine infertility evaluation at an infertility clinic: "NZOZ Medical Center Co. Prof. dr. hab. med. Wiesław Szymański, Dr. med. Marek Szymański" and "Almed - Genito-Urinary Medicine Clinic - dr G. Ludwikowski." The inclusion criteria were male partners of infertile couples and attending fertility clinic for fertility evaluation [infertility is "a disease of the reproductive system defined by the failure to achieve a clinical pregnancy after 12 months or more of regular unprotected sexual intercourse" (Zegers-Hochschild et al. 2009)]. All men underwent evaluation, which included medical history, clinical examination, and semen analysis. All participants agreed to participate in the study. The exclusion criteria were occupational exposure to any toxicant, radiation, or heat; or any other reason for their partners's infertility such as semen anomalies; and the use of any medication with proven influence on male fertility within 3 months before semen analysis. All participants were age between 18 and 50 years, fulfilling inclusion criteria, and no men were excluded. 
Each man was interviewed, and a questionnaire was used to receive the following information:

1. Alcohol use Information about alcohol use included alcohol consumption status (nondrinkers/drinkers) and amount of alcohol consumed (in grams of alcohol per week. Men answering that they "never' used alcohol (0 grams of alcohol/week) were defined as nondrinkers; subjects with a consumption of $<150 \mathrm{~g}$ alcohol/week were defined as moderate drinkers; and those consuming $>150 \mathrm{~g}$ alcohol/week were defined as high drinkers.

2. Tobacco use Information about tobacco use included tobacco use status (smokers/nonsmokers, short-term/long-term smokers), amount, and duration (in years). Men answering that they "never" used tobacco were defined as nonsmokers. Subjects who had smoked for $<1$ year were defined as short-term smokers. Those who had smoked from 1 to 5 years were defined as medium-term smokers. Males who had smoked for >5-10 years were defined as long-term smokers. Man who had smoked for $>10$ years were defined as extremely long-term smokers).

We took account the principles and criteria of the World Health Organization (WHO 2010) procedures for sperm collection, analysis, and definitions in our studies. Thus, after a period of 3-7 days of abstinence, semen samples were collected in sterile containers. After liquefaction, semen analysis was performed according to the WHO guidelines to obtain volume, sperm concentration, motility, and morphology (WHO 2010). Ejaculate volume (ml) was evaluated directly in measuring cylinder (0.1-ml accuracy); sperm concentration $\left(\times 10^{6} \mathrm{ml}^{-1}\right)$ was determined using a counting chamber; motility $(\%)$ was determined at $\times 400$ magnification with phase-contrast optics (200 spermatozoa were counted/semen sample); and percentage of morphologically normal spermatozoa was evaluated using DiffQuick stain by analyzing 100 spermatozoa/semen sample (sperm morphology was rated according to the WHO guidelines criteria). Normal semen values (according to the WHO criteria) are as follows: volume $\geq 1.5 \mathrm{ml}$; sperm concentration $\geq 15 \times 10^{6} / \mathrm{ml}$ of semen; motility $\geq 32 \%$ spermatozoa with progressive motility; and morphologically normal spermatozoa $\geq 4 \%$ (WHO 2010).

Participants were divided into two groups based on their ejaculate parameters. Group I consisted of healthy male partners of infertile couples with normal ejaculate [normozoospermia; $N=83$ (unknown fertility)] and also served as the control group. Group II consisted of males identified as having semen anomalies as the only reason for their infertility with abnormal volume of semen, abnormal concentration, morphology, or motility of spermatozoa; males with more than one abnormal semen variables; and males with no spermatozoa in the ejaculate $(N=85)$.

\section{La, Ce, Eu, Gd, and Ca Analysis in Semen}

Seminal La, Ce, Eu, Gd, and Ca were measured in 162 of 168 samples (group I $N=80$; group II $N=82$ ). The method used for determination of $\mathrm{La}, \mathrm{Ce}, \mathrm{Eu}, \mathrm{Gd}$, and $\mathrm{Ca}$ concentrations in semen samples is described elsewhere (Marzec-Wróblewska et al. 2011). In brief, 1-1.5 ml of semen sample were evaporated in a mineralizer (Tusnovics firm) first at $105{ }^{\circ} \mathrm{C}$ then at $450{ }^{\circ} \mathrm{C}(14 \mathrm{~h})$. Then $3 \mathrm{ml}$ of 69.0-70.0\% nitric acid (Baker Instra analyzed) was added to each sample. After mixing, samples were located in aluminum mineralizer and heated first at $100{ }^{\circ} \mathrm{C}(1 \mathrm{~h})$ and then at $150{ }^{\circ} \mathrm{C}(1 \mathrm{~h})$. The semen samples were poured with $1 \mathrm{ml}$ of $\mathrm{H}_{2} \mathrm{O}_{2}(35 \%)$ and heated at $100{ }^{\circ} \mathrm{C}(1 \mathrm{~h})$. After self-cooling, $6 \mathrm{ml}$ of bidistilled water was added, and a solution was mixed up. $\mathrm{La}, \mathrm{Ce}, \mathrm{Eu}, \mathrm{Gd}$, and $\mathrm{Ca}$ concentrations in semen samples were determined using inductively coupled plasma-mass spectrometry (ICP-MS; 7500CE-Agilent ICP-MS; Agilent, Palo Alto, California, USA). Recoveries were assessed trough sample dilution. Five-fold diluted samples showed differences in concentrations compared with the original sample, which was $<20 \%$. The limit of detection for $\mathrm{La}$ and $\mathrm{Ce}$ was $0.3 \mu \mathrm{g} \mathrm{kg}^{-1}$, for $\mathrm{Eu}$ and $\mathrm{Gd}$ was $0.3 \mathrm{ng} \mathrm{kg}^{-1}$, and for $\mathrm{Ca}$ was $0.33 \mu \mathrm{g} \mathrm{kg}^{-1}$. limit of quantification for $\mathrm{La}$ and $\mathrm{Ce}$ was $0.9 \mu \mathrm{g} \mathrm{kg}^{-1}$, for $\mathrm{Eu}$ and $\mathrm{Gd}$ was $0.9 \mathrm{ng} \mathrm{kg}^{-1}$, and for Ca was $0.33 \mu \mathrm{g} \mathrm{kg}^{-1}$. Precision of the measurements for $\mathrm{La}, \mathrm{Ce}, \mathrm{Eu}, \mathrm{Gd}$, and $\mathrm{Ca}$ was 9, 7, 12, 10, and $8 \%$, respectively. In the determination of $\mathrm{Eu}, 35 \%$ of samples were lower than the method detection limit (MDL). For $\mathrm{Gd}, \mathrm{Ce}, \mathrm{La}$, and $\mathrm{Ca}$ no results were lower than the MDL.

\section{Statistical Analysis}

The medians were calculated and analyzed using computer program Statistica StatSoft, version 10.0 (StatSoft, College Station, Pennsylvania, USA). The median values of La, Ce, $\mathrm{Eu}, \mathrm{Gd}$, and $\mathrm{Ca}$ semen concentrations were compared using U-Mann-Whitney and Kruskal-Wallis tests. The relationships between $\mathrm{La}, \mathrm{Ce}, \mathrm{Eu}, \mathrm{Gd}$, and $\mathrm{Ca}$ semen concentrations and semen-quality parameters were calculated using Spearman's rank correlation coefficients, and $p<0.05$ was regarded as significant. Results lower than the detection limit were excluded from statistical analysis. Data analyses were performed in the three groups of men: a group of all individuals, group I (normozoospermic men), and group II (men with a pathological spermiogram). Ethical approval was obtained for this study from the Local Committee of Bioethics of Nicolaus Copernicus University in Torun, Collegium Medicum in Bydgoszcz (KB/538/2007). 


\section{Results}

\section{Concentrations of REEs and Ca in Semen}

The concentration of $\mathrm{La}$ in semen of Polish men was 2.27-269 $\mu \mathrm{g} \mathrm{kg}^{-1}$ dry weight (dw) (median 19.5). The semen content of $\mathrm{Ce}$ was $41.9 \mu \mathrm{g} \mathrm{kg}^{-1} \mathrm{dw}$ (median 4.52-167). Concentration of $\mathrm{Ce}$ was the lowest of the measured REEs and was $0.68 \mu \mathrm{g} \mathrm{kg}^{-1} \mathrm{dw}$ (median $0.06-1.95)$. The range of $\mathrm{Gd}$ content in semen was from 0.38 to $12.0 \mu \mathrm{g} \mathrm{kg}^{-1} \mathrm{dw}$ (median 3.19). In the present study, the range of seminal $\mathrm{Ca}$ content was from 484 to $17,191 \mathrm{mg} \mathrm{kg}^{-1} \mathrm{dw}$ (median 4063). Our study also showed that semen of men from group I had greater La, Ce, and Gd concentrations than semen of men from group II, but the differences were not significant. Median concentration of $\mathrm{Eu}$ in semen of group I and II males was similar. The concentration of $\mathrm{Ca}$ in semen of group I males was lower than in semen from group II men [the difference was not significant (Table 1)].

\section{Alcohol}

In the group of all men (group I + II) and group II (males with a pathological spermiogram), concentrations of La, $\mathrm{Ce}, \mathrm{Eu}, \mathrm{Gd}$, and $\mathrm{Ca}$ ( $\mathrm{Eu}$ and $\mathrm{Ca}$ only in group II) was significantly lower in nondrinkers' semen than in semen from drinkers (Table 2). A significant difference was detected in the group of all men (group I + II) and group II (males with pathological spermiogram) between La, Ce, $\mathrm{Gd}$, and $\mathrm{Ca}$ ( $\mathrm{Gd}$ and $\mathrm{Ca}$ also only in group II) concentrations in semen from nondrinkers and that from moderate drinkers (Table 3).

\section{Tobacco}

In the group of all men (group I + II) and group II (males with pathological spermiogram), concentrations of $\mathrm{La}, \mathrm{Ce}$, and Gd in semen of short-term smokers were significantly lower than those in semen of extremely long-term smokers (Table 4). A significant difference was also detected in the group of all men (group I + II) between La concentration in semen compared with that from short-term smokers and long-term smokers (Table 4).

\section{Correlations}

We found a significant positive correlation between $\mathrm{La}, \mathrm{Ce}$, $\mathrm{Eu}, \mathrm{Gd}$, and $\mathrm{Ca}$ concentrations in semen. In the group of all males, concentrations of $\mathrm{La}, \mathrm{Ce}$, and $\mathrm{Gd}$ in semen were positively associated with progressive motility and percentage of normal spermatozoa. In group I (normozoospermic males), $\mathrm{La}, \mathrm{Gd}$ and $\mathrm{Ca}$ concentrations were also positively associated with progressive motility and percentage of normal spermatozoa, whilst the concentration of Ce was negatively correlated with the percentage of spermatozoa with progressive motility. We also found a significant positive correlation between Ce concentration in semen and percentage of normal spermatozoa and between $\mathrm{Ca}$ and sperm concentration. In group II (males with pathological spermiogram), concentrations of $\mathrm{La}, \mathrm{Ce}$, and Gd in semen were negatively associated with sperm concentration, whereas $\mathrm{Ca}$ concentration was negatively associated with volume of ejaculate (Table 5). Our study show that increased seminal Ca level was associated with increased progressive motility, sperm concentration, and percentage of normal sperm cells.

Table 1 Characteristics of semen in the group of normozoospermic males (group I) and the group of males with abnormal semen values (group II)

\begin{tabular}{|c|c|c|c|c|c|c|c|c|}
\hline \multirow[t]{2}{*}{ Semen characteristics } & \multicolumn{3}{|c|}{ Group I } & \multicolumn{3}{|c|}{ Group II } & \multirow[t]{2}{*}{$Z$} & \multirow[t]{2}{*}{$p$} \\
\hline & $N$ & Median & Minimum-maximum & $N$ & Median & Minimum-maximum & & \\
\hline Ejaculate volume (ml) & 83 & 3.75 & $1.50-8.00$ & 85 & 3.50 & $0.40-10.3$ & -1.32 & 0.19 \\
\hline Progressive motility (\%) & 83 & 58.8 & $32.2-84.1$ & 85 & 12.69 & $0.00-70.0$ & -9.97 & 0.00 \\
\hline Normal morphology (\%) & 83 & 85.7 & $58.9-99.8$ & 85 & 63.89 & $0.00-100$ & -5.73 & $\mathbf{0 . 0 0}$ \\
\hline Sperm concentration $(\times 106 / \mathrm{ml})$ & 83 & 85.5 & $16.0-260$ & 85 & 12.80 & $0.00-343$ & -7.60 & $\mathbf{0 . 0 0}$ \\
\hline La concentration $(\mu \mathrm{g} / \mathrm{kg} \mathrm{dw})$ & 80 & 21.5 & $2.27-269$ & 82 & 17.5 & $2.58-79.0$ & -0.98 & 0.33 \\
\hline Ce concentration $(\mu \mathrm{g} / \mathrm{kg} \mathrm{dw})$ & 80 & 44.0 & $4.52-140$ & 82 & 37.9 & $4.63-167$ & -1.07 & 0.28 \\
\hline Eu concentration $(\mu \mathrm{g} / \mathrm{kg} \mathrm{dw})$ & 52 & 0.68 & $0.06-1.54$ & 52 & 0.68 & $0.44-1.95$ & -0.32 & 0.75 \\
\hline Gd concentration $(\mu \mathrm{g} / \mathrm{kg} \mathrm{dw})$ & 80 & 3.38 & $0.38-12.0$ & 82 & 2.98 & $0.44-11.4$ & -1.12 & 0.26 \\
\hline Ca concentration $(\mathrm{mg} / \mathrm{kg} \mathrm{dw})$ & 80 & 3927 & $484-7303$ & 82 & 4130 & $2126-17,191$ & 1.14 & 0.25 \\
\hline
\end{tabular}

Statistically significant differences are shown in bold type

Comparison of the results of groups of semen samples $(p<0.05)$ 
Table 2 Concentrations of $\mathrm{La}, \mathrm{Ce}, \mathrm{Eu}, \mathrm{Gd}$, and $\mathrm{Ca}$ in semen of drinkers and nondrinkers in the group of normozoospermic males (group I), the group of males with abnormal serum values (group II), and both groups combined

\begin{tabular}{|c|c|c|c|c|c|c|c|c|c|}
\hline & \multicolumn{3}{|c|}{ All individuals } & \multicolumn{3}{|c|}{ Group I } & \multicolumn{3}{|c|}{ Group II } \\
\hline & $N$ & $\begin{array}{l}\text { Median (minimum- } \\
\text { maximum) }\end{array}$ & $p$ & $N$ & $\begin{array}{l}\text { Median (minimum- } \\
\text { maximum) }\end{array}$ & $p$ & $N$ & $\begin{array}{l}\text { Median (minimum- } \\
\text { maximum) }\end{array}$ & $p$ \\
\hline \multicolumn{10}{|c|}{ La concentration $(\mu \mathrm{g} / \mathrm{kg} \mathrm{dw})$} \\
\hline Nondrinkers & 36 & $16.2^{\mathrm{a}}(3.05-5.52)$ & 0.00 & 20 & $21.1(4.14-55.2)$ & 0.60 & 16 & $8.04^{\mathrm{d}}(3.05-21.8)$ & 0.00 \\
\hline Drinkers & 114 & $21.8^{\mathrm{a}}(2.27-268)$ & & 53 & $24.0(2.27-269)$ & & 61 & $21.2^{\mathrm{d}}(2.58-64.1)$ & \\
\hline \multicolumn{10}{|c|}{ Ce concentration $(\mu \mathrm{g} / \mathrm{kg} \mathrm{dw})$} \\
\hline Nondrinkers & 36 & $33.3^{\mathrm{b}}(5.37-115)$ & 0.01 & 20 & $42.4(8.97-115)$ & 0.58 & 16 & $16.2^{\mathrm{e}}(5.37-42.7)$ & 0.00 \\
\hline Drinkers & 114 & $44.3^{\mathrm{b}}(4.52-140)$ & & 53 & $49.0(4.52-140)$ & & 61 & $43.1^{\mathrm{e}}(4.63-140)$ & \\
\hline \multicolumn{10}{|c|}{ Eu concentration $(\mu \mathrm{g} / \mathrm{kg} \mathrm{dw})$} \\
\hline Nondrinkers & 18 & $0.64(0.46-1.54)$ & 0.26 & 13 & $0.64(0.52-1.54)$ & 0.85 & 16 & $0.54^{\mathrm{f}}(0.46-0.71)$ & 0.03 \\
\hline Drinkers & 80 & $0.69(0.06-1.95)$ & & 53 & $0.68(0.06-1.34)$ & & 61 & $0.69^{\mathrm{f}}(0.44-1.95)$ & \\
\hline \multicolumn{10}{|c|}{ Gd concentration $(\mu \mathrm{g} / \mathrm{kg} \mathrm{dw})$} \\
\hline Nondrinkers & 36 & $2.69^{\mathrm{c}}(0.44-9.21)$ & 0.01 & 20 & $3.28(1.03-9.21)$ & 0.71 & 16 & $1.38^{\mathrm{g}}(0.44-3.55)$ & $\mathbf{0 . 0 0}$ \\
\hline Drinkers & 114 & $3.47^{\mathrm{c}}(0.38-12.0)$ & & 53 & $3.79(0.38-12.0)$ & & 61 & $3.26^{\mathrm{g}}(0.50-9.87)$ & \\
\hline \multicolumn{10}{|c|}{ Ca concentration $(\mathrm{mg} / \mathrm{kg} \mathrm{dw})$} \\
\hline Nondrinkers & 36 & $3842(2126-7303)$ & 0.12 & 20 & $4456(2590-7303)$ & 0.24 & 16 & $2885^{\mathrm{h}}(2126-5856)$ & $\mathbf{0 . 0 0}$ \\
\hline Drinkers & 114 & $3964(484-14,617)$ & & 53 & $3734(484-7070)$ & & 61 & $4318^{\mathrm{h}}(2232-14,617)$ & \\
\hline
\end{tabular}

Statistically significant differences are shown in bold type

Medians indicated with identical superscript letters are statistically different $(p<0.05)$

\section{Discussion}

To the best of our knowledge, this is the first time that the contents of rare earth elements in human semen has been determined. Concentrations of $\mathrm{La}, \mathrm{Ce}, \mathrm{Eu}$, and $\mathrm{Gd}$ in semen of Polish men were 19.5, 41.9, 0.68, and $3.19 \mu \mathrm{g} \mathrm{kg}^{-1} \mathrm{dw}$, respectively. There are no data concerning this subject in the literature. However, we found some information about concentrations of this element in blood, serum, urine, teeth, and hair. Concentrations of $\mathrm{La}$ and $\mathrm{Ce}$ in blood plasma of adult males and females living in northern Germany ranged from "not traceable" to $20 \mathrm{ng} \mathrm{l}^{-1}$ for La and to $30 \mathrm{ng} \mathrm{1^{-1 }}$ for Ce (Heitland and Köster 2006). Rodushkin et al. (1999) reported that $\mathrm{La}$ and $\mathrm{Ce}$ concentrations in serum $(3.3 \pm 1.7$ and $45 \pm 24 \mathrm{ng} \mathrm{ml}^{-1}$, respectively) were significantly greater than data from a study by Morita et al. (1994), i.e., $0.17 \pm 0.2$ and $0.40 \pm 0.19 \mathrm{ng} \mathrm{ml}^{-1}$, respectively. Minoia et al. (1990), who determined concentrations of the elements in urine, blood, and serum (plasma) of the Italian population from 1990, reported that concentrations of $\mathrm{La}$, $\mathrm{Ce}$, and $\mathrm{Eu}$ in urine were $0.73 \pm 0.55,3.1 \pm 1.95$, $0.11 \pm 0.08$, and $<1 \mu \mathrm{g} \mathrm{l}^{-1}$, respectively. The mean values of these elements in blood at the micrograms per liter level were $1.42 \pm 0.71(\mathrm{La}), 3.1 \pm 2.15(\mathrm{Ce}), 0.21 \pm 0.08(\mathrm{Eu})$, whereas $\mathrm{Gd}$ in urine and $\mathrm{La}$ in serum were at concentrations $<1 \mu \mathrm{g}^{-1}$. Peng et al. (2003) examined the concentration of $\mathrm{La}$ in the hair of young children ( $0-3$ years) and their mothers living in a rare earth mining area. The mean hair content of La was greatest (2203 $\mathrm{ng} \mathrm{g}^{-1}$ ) in young children living nearest to the REE-mining area. The next greatest (472 $\mathrm{ng} \mathrm{g}^{-1}$ ) was in those living nearer to the REEs mining area, and the lowest content $\left(97.4 \mathrm{ng} \mathrm{g}^{-1}\right)$ was in those living in the control area. The REE content in the mothers' hair was $1510 \mathrm{ng} \mathrm{g}^{-1}$ in the high-exposure area, $242 \mathrm{ng} \mathrm{g}^{-1}$ in the low-exposure area, and $59.2 \mathrm{ng} \mathrm{g}^{-1}$ in the control area. Brown et al. (2004) compared La and Ce contents of children's primary teeth from Uganda and the UK. Teeth from Ugandan children's contained a significantly greater concentration of La than the teeth in children from the UK $\left(0.001-0.07\right.$ and $0.04-0.28 \mathrm{mg} \mathrm{kg}^{-1}$ respectively). The range of $\mathrm{Ce}$ concentration was greater in teeth in Ugandan children $\left(0.04-0.36 \mathrm{mg} \mathrm{kg}^{-1}\right)$ compared with teeth in children from the UK $\left(0.005-0.09 \mathrm{mg} \mathrm{kg}^{-1}\right)$. The precise mechanism by which these elements are transferred from the circulatory blood into semen is unclear. In the present study, the median value of seminal Ca content was $4063 \mathrm{mg} \mathrm{kg}^{-1} \mathrm{dw}$. Surprisingly, communications in this specific field are also rather limited. Seminal concentration of $\mathrm{Ca}$ was reported by Sørensen et al. (1999) as between 391 and $672 \mathrm{mg} \mathrm{l}^{-1}$. Valsa et al. (2012) found a Ca concentration in seminal plasma ranging from 8 to $324 \mathrm{mg} \mathrm{dl}^{-1}$ and in spermatozoa from 1.58 to $198 \mathrm{mg} \mathrm{dl}^{-1}$.

The median values of $\mathrm{La}, \mathrm{Ce}$, and $\mathrm{Gd}$ concentrations in semen of normospermic men were greater than in semen in men from group II, whereas the concentration of Eu was 
Table 3 Concentrations of $\mathrm{La}, \mathrm{Ce}, \mathrm{Eu}, \mathrm{Gd}$ and $\mathrm{Ca}$ in semen of nondrinkers, moderate drinkers, and high drinkers in the group of normozoospermic males (group I), the group of males with abnormal values of semen (group II), and both groups combined

\begin{tabular}{|c|c|c|c|c|c|c|c|c|c|}
\hline & \multicolumn{3}{|c|}{ All individuals } & \multicolumn{3}{|c|}{ Group I } & \multicolumn{3}{|c|}{ Group II } \\
\hline & $N$ & $\begin{array}{l}\text { Median (minimum- } \\
\text { maximum) }\end{array}$ & $p$ & $N$ & $\begin{array}{l}\text { Median (minimum- } \\
\text { maximum) }\end{array}$ & $p$ & $N$ & $\begin{array}{l}\text { Median (minimum- } \\
\text { maximum) }\end{array}$ & $p$ \\
\hline \multicolumn{10}{|c|}{ La concentration $(\mu \mathrm{g} / \mathrm{kg} \mathrm{dw})$} \\
\hline Nondrinkers & 36 & $16.2^{\mathrm{a}}(3.05-5.52)$ & 0.01 & 20 & $21.1(4.14-55.2)$ & 0.84 & 16 & $8.04^{\mathrm{d}}(3.05-21.8)$ & 0.00 \\
\hline Moderate drinkers & 102 & $22.1^{\mathrm{a}}(2.27-269)$ & & 48 & $24.7(2.27-269)$ & & 54 & $21.5^{\mathrm{d}}(2.97-64.1)$ & \\
\hline High drinkers & 12 & $19.3(2.58-59.4)$ & & 5 & $22.6(12.5-41.0)$ & & 7 & $16.7(2.58-59.4)$ & \\
\hline \multicolumn{10}{|c|}{ Ce concentration $(\mu \mathrm{g} / \mathrm{kg} \mathrm{dw})$} \\
\hline Nondrinkers & 36 & $33.3^{\mathrm{b}}(5.37-115)$ & 0.02 & 20 & $42.4(8.97-115)$ & 0.82 & 16 & $16.2^{\mathrm{e}}(5.37-42.7)$ & $\mathbf{0 . 0 0}$ \\
\hline Moderate drinkers & 102 & $45.0^{\mathrm{b}}(4.52-140)$ & & 48 & $50.1(4.52-140)$ & & 54 & $44.3^{\mathrm{e}}(4.63-140)$ & \\
\hline High drinkers & 12 & $37.2(6.03-120)$ & & 5 & $49.0(23.4-78.7)$ & & 7 & $31.2(6.03-120)$ & \\
\hline \multicolumn{10}{|c|}{ Eu concentration $(\mu \mathrm{g} / \mathrm{kg} \mathrm{dw})$} \\
\hline Nondrinkers & 18 & $0.64(0.46-1.54)$ & 0.51 & 13 & $0.64(0.52-1.54)$ & 0.92 & 16 & $0.54(0.46-0.71)$ & 0.09 \\
\hline Moderate drinkers & 72 & $0.70(0.06-1.95)$ & & 33 & $0.68(0.06-1.34)$ & & 39 & $0.71(0.04-1.95)$ & \\
\hline High drinkers & 8 & $0.65(0.54-1.41)$ & & 5 & $0.65(0.01-0.76)$ & & 7 & $0.67(0.57-0.76)$ & \\
\hline \multicolumn{10}{|c|}{ Gd concentration $(\mu \mathrm{g} / \mathrm{kg} \mathrm{dw})$} \\
\hline Nondrinkers & 36 & $2.69^{\mathrm{c}}(0.44-9.21)$ & 0.03 & 20 & $3.28(1.03-9.21)$ & 0.93 & 16 & $1.38^{\mathrm{f}}(0.44-3.55)$ & $\mathbf{0 . 0 0}$ \\
\hline Moderate drinkers & 102 & $3.61^{\mathrm{c}}(0.38-12.0)$ & & 48 & $3.87(0.38-12.0)$ & & 54 & $3.41^{\mathrm{f}}(0.54-9.87)$ & \\
\hline High drinkers & 12 & $3.26(0.50-8.48)$ & & 5 & $3.42(1.90-5.86)$ & & 7 & $3.25(0.50-8.48)$ & \\
\hline \multicolumn{10}{|c|}{ Ca concentration $(\mathrm{mg} / \mathrm{kg} \mathrm{dw})$} \\
\hline Nondrinkers & 36 & $3842(2126-7303)$ & 0.24 & 20 & $4456(2590-7303)$ & 0.35 & 16 & $2885^{\mathrm{g}}(2126-5856)$ & 0.00 \\
\hline Moderate drinkers & 102 & $3993(484-14,617)$ & & 48 & $3656(484-7070)$ & & 54 & $4449^{\mathrm{g}}(2455-14,617)$ & \\
\hline High drinkers & 12 & 3904 (2232-6853) & & 5 & 4209 (2758-6225) & & 7 & $3060(2232-6853)$ & \\
\hline
\end{tabular}

Statistically significant differences are shown in bold type

Medians indicated with identical superscript letters are statistically different $(p<0.05)$. Nondrinkers $0 \mathrm{~g}$ of ethanol; moderate drinkers $\leq 150 \mathrm{~g}$ of ethanol; and high drinkers $>150 \mathrm{~g}$ of ethanol

similar and the concentration of Ca was lower. As previously mentioned, we did not find any information about REE concentrations in semen, but it seems, at the examined level, that $\mathrm{La}, \mathrm{Ce}, \mathrm{Eu}$, and $\mathrm{Gd}$ did not affect sperm quality. However, production, maturation, motility, and fertilizing capacity of the spermatozoa might be affected by abnormal levels of Ca (Hong et al. 1984). Similarly, mean seminal $\mathrm{Ca}$ concentration in the fertile group was lower (but not significantly so) than that of the infertile group in research of Wong et al. (2001). This finding also confirms previous reports (Umeyama et al. 1986). Pandy et al. (1983), however, observed a lower concentration of $\mathrm{Ca}$ in semen of subfertile males. In addition, Abou-Shakra et al. (1989) determined the lowest $\mathrm{Ca}$ content in normozoospermic males of their infertile group. Our results were inconsistent with those reported by Logoglu et al. (1997) and Bassey et al. (2013).

The concentrations of REEs and $\mathrm{Ca}$ were lower in nondrinkers' semen than in semen from drinkers. No data have been reported on REE concentrations in the human body and their relationship with alcohol-consumptions habits, but the results of Xiaofei et al. (2013) indicate that soil containing REEs may be the source of REE pollution in foods, and the human body can continually accumulate REEs through food digestion and absorption. We could not find any information either for and or against our findings on $\mathrm{Ca}$ seminal concentration; however the toxic effect of alcohol might manifest, among other things, by a disturbance of chemical element equilibrium in the human body (Ford et al. 1995; Rylander et al. 2001). It is of note that Labib et al. (1989) did not find differences in mean plasma $\mathrm{Ca}$ concentration nor any correlation between plasma ethanol and $\mathrm{Ca}$ concentration. Similarly, Santori et al. (2008) found no significant difference in total and ionised Ca concentration in serum between chronic male alcoholics and healthy controls. In contrast, Bjørneboe et al. (1986) reported a significantly lower concentration of $\mathrm{Ca}$ in serum in alcoholics than in controls. In addition, we found previous reports that ethanol stimulated an increase in intracellular concentration of $\mathrm{Ca}^{2+}$ in cells (Davidson et al. 1990; Konda et al. 1991; Kam et al. 2010). Urinary loss of $\mathrm{Ca}$ induced by ethanol has also been reported (Lusier et al. 1977). The mechanisms leading to the increase in concentration of REEs and $\mathrm{Ca}$ in semen from drinkers are 
Table 4 Concentration of $\mathrm{La}, \mathrm{Ce}, \mathrm{Eu}, \mathrm{Gd}$, and $\mathrm{Ca}$ in semen of nonsmokers, short-term, medium-term smokers, long-term smokers, and extremely long-term smokers, the group of normozoospermic males (group I), the group of males with abnormal semen values (group II), and both groups combined

\begin{tabular}{|c|c|c|c|c|c|c|c|c|c|}
\hline & \multicolumn{3}{|c|}{ All individuals } & \multicolumn{3}{|c|}{ Group I } & \multicolumn{3}{|c|}{ Group II } \\
\hline & $N$ & $\begin{array}{l}\text { Median (minimum- } \\
\text { maximum) }\end{array}$ & $p$ & $N$ & $\begin{array}{l}\text { Median (minimum- } \\
\text { maximum) }\end{array}$ & $p$ & $N$ & $\begin{array}{l}\text { Median (minimum- } \\
\text { maximum) }\end{array}$ & $p$ \\
\hline \multicolumn{10}{|l|}{ La concentration $(\mu \mathrm{g} / \mathrm{kg} \mathrm{dw})$} \\
\hline Never smokers & 81 & $18.9(2.97-75.6)$ & $0.05^{\mathbf{a}}$ & 38 & $22.5(4.14-75.6)$ & \multirow[t]{5}{*}{0.45} & 43 & $16.62(.97-53.8)$ & \multirow[t]{5}{*}{$\mathbf{0 . 0 3}$} \\
\hline Short-term smokers & 14 & $9.50^{\mathrm{a}, \mathrm{b}}(2.27-43.3)$ & $0.01^{b}$ & 7 & $9.99(2.27-43.3)$ & & 7 & $18.2^{\mathrm{e}}(7.74-60.2)$ & \\
\hline Medium-term smokers & 16 & $16.4(6.27-269)$ & & 7 & $15.9(8.66-269)$ & & 9 & $17.0(6.27-32.7)$ & \\
\hline Long-term smokers & 24 & $23.6^{\mathrm{a}}(3.51-65.2)$ & & 12 & $19.5(5.40-55.2)$ & & 12 & $25.0(3.51-65.2)$ & \\
\hline Extremely long-term smokers & 21 & $27.5^{\mathrm{b}}(3.02-79.0)$ & & 12 & $24.8(3.02-46.9)$ & & 9 & $37.1^{\mathrm{e}}(7.59-79.0)$ & \\
\hline \multicolumn{10}{|l|}{ Ce concentration $(\mu \mathrm{g} / \mathrm{kg} \mathrm{dw})$} \\
\hline Never smokers & 81 & $40.2(4.63-136)$ & \multirow[t]{5}{*}{0.01} & 38 & $47.5(8.92-136)$ & \multirow[t]{5}{*}{0.47} & 43 & $36.2(4.63-109)$ & \multirow[t]{5}{*}{$\mathbf{0 . 0 3}$} \\
\hline Short-term smokers & 14 & $18.7^{\mathrm{c}}(4.52-93.5)$ & & 7 & $22.8(4.52-93.5)$ & & 7 & $18.2^{\mathrm{f}}(7.74-60.2)$ & \\
\hline Medium-term smokers & 16 & $33.5(12.1-140)$ & & 7 & $29.8(13.0-140)$ & & 9 & $37.1(12.1-67.5)$ & \\
\hline Long-term smokers & 24 & $51.4(6.03-140)$ & & 12 & $38.9(9.17-115)$ & & 12 & $55.0(6.03-140)$ & \\
\hline Extremely long-term smokers & 21 & $65.7^{\mathrm{c}}(6.04-167)$ & & 12 & $49.4(6.04-103)$ & & 9 & $82.0^{\mathrm{f}}(14.4-167)$ & \\
\hline \multicolumn{10}{|l|}{ Eu concentration $(\mu \mathrm{g} / \mathrm{kg} \mathrm{dw})$} \\
\hline Never smokers & 53 & $0.64(0.15-1.34)$ & \multirow[t]{5}{*}{0.31} & 27 & $0.65(0.15-1.34)$ & \multirow[t]{5}{*}{0.65} & 26 & $0.62(0.44-1.20)$ & \multirow[t]{5}{*}{0.40} \\
\hline Short-term smokers & 5 & $0.78(0.06-0.90)$ & & 3 & $0.78(0.06-0.90)$ & & 2 & $0.70(0.59-0.81)$ & \\
\hline Medium-term smokers & 9 & $0.71(0.54-1.08)$ & & 7 & $0.90(0.54-1.08)$ & & 9 & $0.69(0.55-0.75)$ & \\
\hline Long-term smokers & 16 & $0.77(0.49-1.95)$ & & 12 & $0.68(0.49-1.53)$ & & 12 & $0.77(0.54-1.95)$ & \\
\hline Extremely long-term smokers & 17 & $0.70(0.53-1.42)$ & & 9 & $0.70(0.57-1.14)$ & & 9 & $0.76(0.53-1.42)$ & \\
\hline \multicolumn{10}{|l|}{ Gd concentration $(\mu \mathrm{g} / \mathrm{kg} \mathrm{dw})$} \\
\hline Never smokers & 81 & $3.15(0.44-12.0)$ & \multirow[t]{5}{*}{$\mathbf{0 . 0 0}$} & 38 & $3.55(0.56-12.0)$ & \multirow[t]{5}{*}{0.35} & 43 & $2.89(0.44-7.77)$ & \multirow[t]{5}{*}{0.03} \\
\hline Short-term smokers & 14 & $1.57^{\mathrm{d}}(0.38-6.32)$ & & 7 & $1.54(0.38-6.32)$ & & 7 & $1.60^{\mathrm{g}}(0.70-4.85)$ & \\
\hline Medium-term smokers & 16 & $2.66(0.96-7.55)$ & & 7 & $2.56(1.18-7.55)$ & & 9 & $2.77(0.96-4.97)$ & \\
\hline Long-term smokers & 24 & $3.80(0.50-9.87)$ & & 12 & $2.84(1.08-9.21)$ & & 12 & $3.83(0.50-9.87)$ & \\
\hline Extremely long-term smokers & 21 & $4.58^{\mathrm{d}}(0.75-11.4)$ & & 12 & $4.15(0.75-7.10)$ & & 9 & $5.77^{\mathrm{g}}(1.05-11.4)$ & \\
\hline \multicolumn{10}{|l|}{ Ca concentration $(\mathrm{mg} / \mathrm{kg} \mathrm{dw})$} \\
\hline Never smokers & 81 & $3889(1111-10,305)$ & \multirow[t]{5}{*}{0.04} & 38 & $3833(1111-6816)$ & \multirow[t]{5}{*}{0.59} & 43 & $3889(2126-10,305)$ & \multirow[t]{5}{*}{0.08} \\
\hline Short-term smokers & 14 & $3207(484-7083)$ & & 7 & $3312(484-5739)$ & & 7 & $3102(2232-7083)$ & \\
\hline Medium-term smokers & 16 & 3992 (2659-6276) & & 7 & 4098 (2659-5517) & & 9 & $3886(2699-6276)$ & \\
\hline Long-term smokers & 24 & $4637(2620-17,191)$ & & 12 & $4042(2825-7303)$ & & 12 & $5330(2620-17,191)$ & \\
\hline Extremely long-term smokers & 21 & $4809(1719-14,617)$ & & 12 & $4214(1719-5863)$ & & 9 & $5138(3060-14,617)$ & \\
\hline
\end{tabular}

Statistically significant differences are shown in bold type

Medians indicated with identical letters are statistically different $(p<0.05)$. Short-term smokers $<1$ year; medium-term smokers $1-<5$ years; long-term smokers $5-<10$ years; and extremely long-term smokers $\geq 10$ years

obscure. It must be emphasized that alcohol is not only a chemical substance but also some kind of nutrient and as a nutrient it affects tissue metabolism (Forsander 1998).

Our study shows that concentrations of $\mathrm{La}, \mathrm{Ce}$, and $\mathrm{Gd}$ in semen are increased with increasing duration of smoking. Data concerning this subject in the literature are scarce. Gerhardsson et al. (1985) and Gerhardsson and Nordberg (1993) found no significant differences in lung tissue La content between smokers, ex-smokers, and nonsmokers, whereas Gómez-Aracena et al. (2006) found a significant relationship between $\mathrm{Ce}$ concentration and smoking. It is commonly known that cigarette smoke is a complex mixture of particulate matter and numerous gaseous compounds. However, we could not find good data on $\mathrm{La}, \mathrm{Ce}$, and $\mathrm{Gd}$ contents in cigarettes. Environmental tobacco smoke (ETS) is one the most relevant and crucial factors for indoor air quality and is classified as being carcinogenic to humans. It contains many trace and toxic elements including heavy metals and rare earth elements. However, for some elements, data are scarce, and little attention has been paid to $\mathrm{Ce}, \mathrm{La}$, and Ga contents in ETS. There is no reference to $\mathrm{Cd}, \mathrm{Ce}, \mathrm{La}$, and $\mathrm{Gd}$ in the 


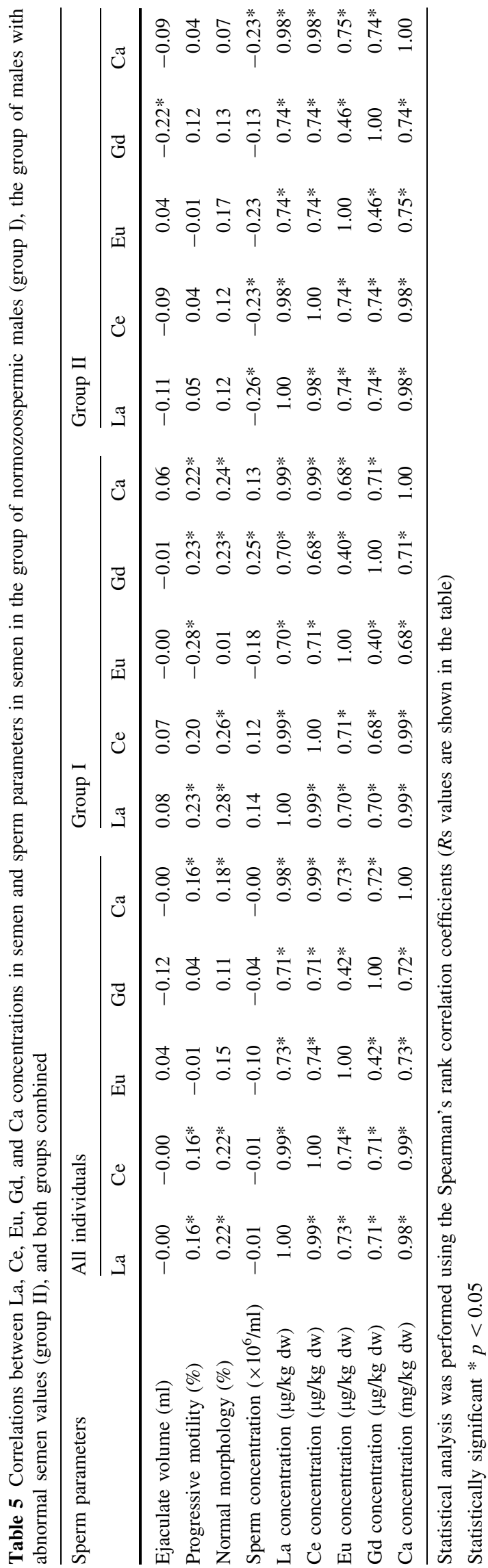

comprehensive reviews of the International Agency for Research on Cancer (2004) and the United States Department of Health and Human Services (2006). Remarkably, very high concentrations for $\mathrm{Ce}$ and $\mathrm{La}$ were found in indoor places with moderate or heavy tobacco-smoking activity (Böhlandt et al. 2012). The prevalent source for $\mathrm{Ce}$ and $\mathrm{La}$ in indoor air appears to be due to tobacco smoke as has already shown by Bolte et al. (2008), Slezakova et al. (2009), and Fromme et al. (2009). As all elements, REEs are present in the atmosphere, water, soil and plants, but, it must be emphasized that REEs are elements with low mobility, and thus they can accumulate in such environments (Cao et al. 2001; Zhang and Shan 2001; Aquino et al. 2009). Thus, long-term intake of small doses of REEs could not be considered as being irrelevant for humans. In addition, human beings are at the top of the food chain; therefore, health damage caused by long-term exposure to REEs from water, food or, e.g., cigarette smoke, should not be neglected.

Our study shows positive correlations between $\mathrm{La}, \mathrm{Ce}$, $\mathrm{Eu}, \mathrm{Gd}$, and $\mathrm{Ca}$ concentrations in semen. Lanthanides act as $\mathrm{Ca}$ analogues in biological systems, and trivalent lanthanide ions can replace $\mathrm{Ca}$ at metal-binding sites (Wang et al. 1982; Lansman 1990; Nishimura 1993; Reeves and Condrescu 2003; Ardón et al. 2009; Carrillo-López et al. 2010). Seminal $\mathrm{La}, \mathrm{Ce}$, and $\mathrm{Gd}$ concentrations were positively associated with progressive motility and percentage of normal spermatozoa and negatively with sperm concentration. Ce content was negatively correlated with percentage of spermatozoa with progressive motility. $\mathrm{Ca}$ concentration in semen was positively associated with progressive motility, normal morphology, and sperm concentration and negatively associated with volume of ejaculate. Only a handful of reports of the impact of ionized REEs on semen quality were found in the literature. Lee et al. (1981) showed that $\mathrm{La}^{3+}$ and $\mathrm{Eu}^{3+}$ inhibited motility stimulation in the presence of $\mathrm{Ca}$ and that the IC50 values for both ions were approximately $5 \times 10^{-5} \mathrm{M}$. In addition, Saling (1982) reported that sperm immotility in the presence of $\mathrm{La}^{3+}$ can be reversed immediately by incubation with $\mathrm{Ca}^{2+}$ and, furthermore, that the state of immobilization produced by $\mathrm{La}^{3}+$ did not affect sperm adversely. In Oral et al. (2010), both $\mathrm{Ce}^{4+}$ and $\mathrm{La}^{3+}$ caused a decrease in sperm fertilization rate at the highest tested concentration $\left(10^{-5} \mathrm{M}\right)$. Our results do not support this finding; however, it must be emphasized that we measured total concentrations of $\mathrm{La}, \mathrm{Ce}$, and $\mathrm{Gd}$ in semen and not the effect on spermatozoa of ionized form of this elements. Studies on the relationship between $\mathrm{Ca}$ and semen parameters are contradictory. Our study showed that increased seminal Ca levels were associated with increased progressive motility, sperm concentration, and percentage of normal sperm cells. These findings are in accordance with Bassey et al. 
(2013) who also found significant positive correlation between Ca and percentage motility. However, Arver (1982) showed that a high $\mathrm{Ca}$ concentration decreased sperm motility. In contrast, Logoglu et al. (1997) and Wong et al. (2001) found no significant relationships between seminal Ca concentration and sperm density or percentage motility. When our results are evaluated with those of other reports, it may be hypothesized that seminal Ca may be involved in semen quality and that this effect can be stimulatory or inhibitory depending on its concentration. Normal sperm motility, and all other processes leading to fertilization, required an optimal seminal concentration of $\mathrm{Ca}$ (Fraser 1987). All of these findings suggest that seminal $\mathrm{Ca}$ is an important factor in male fertility.

For the first time, the contents of REEs in human semen were determined and described. Similarly, REE relationships with semen quality, concentration of seminal $\mathrm{Ca}$, and lifestyle habits were reported for the first time. Summarizing our results, although we could not unequivocally prove the influence of $\mathrm{La}, \mathrm{Ce}, \mathrm{Eu}$, and $\mathrm{Gd}$ concentrations on sperm quality as a whole, we found both positive and negative association of $\mathrm{La}, \mathrm{Ce}, \mathrm{Eu}$ and $\mathrm{Gd}$ concentrations with semen-quality parameters, i.e., volume of ejaculate, sperm concentration, motility, and morphology. In addition, our findings suggest that alcohol consumption and smoking might increase levels of REEs in semen. However, it is unclear how these elements are transferred into the semen, and a review of the literature reveals that there is little information about the possible impact of REEs on human health. Therefore, further research on $\mathrm{La}, \mathrm{Ce}, \mathrm{Eu}$, and $\mathrm{Gd}$ and the toxicological, human, and public health consequences is urgently required.

Acknowledgments This work was supported by a grant from the Rector Magnificus of Nicolaus Copernicus University in Torun (Grant No. 47-2008). This work was supported by funds from the European Social Fund and State budget within the framework of the Integrated Program of Operating Regional Development, the Activity 2.6 "Regional Innovative Strategies and Knowledge Transfer" of individual project of the Kuyavian-Pomeranian Province: Scholarships for Graduate Students of 2008/2009-ZPORR. This work was supported by maintain a research capacities funds from Nicolaus Copernicus University in Torun (DS-UPB 469/2015). We thank Brendan P. Kavanagh (Royal College of Surgeons in Ireland, Medical University of Bahrain) for help with improving the English language of the paper.

Open Access This article is distributed under the terms of the Creative Commons Attribution License which permits any use, distribution, and reproduction in any medium, provided the original author(s) and the source are credited.

\section{References}

Abou-Shakra FR, Ward NI, Everard DM (1989) The role of trace elements in male infertility. Fertil Steril 52:307-310
Aquino LD, Morgana M, Carboni MA, Staiano M, Antisari MV, Lorito M et al (2009) Effect of some rare earth elements on the growth and lanthanide accumulation in different Trichoderma strains. Soil Biol Biochem 41:2406-2413

Ardón F, Rodríguez-Miranda E, Beltrán C, Hernández-Cruz A, Darszon A (2009) Mitochondrial inhibitors activate influx of external $\mathrm{Ca} 2+$ in sea urchin sperm. Biochim Biophys Acta 1787:15-24

Arver S (1982) Studies on zinc and calcium in human seminal plasma. Acta Physiol Scand 507(Suppl):1-21

Bassey IE, Essien OE, Udoh AE, Imo IU, Effiong IO (2013) Seminal plasma selenium, calcium, magnesium and zinc levels in infertile men. J Med Sci 13:483-487

Basu A, Chakrabarty K, Chatterjee GC (1982) Neurotoxicity of lanthanum chloride in newborn chicks. Toxicol Lett 14: $21-25$

Bjørneboe GE, Johnsen J, Bjørneboe A, Rousseau B, Pedersen J, Norum KR et al (1986) Effect of alcohol consumption on serum concentration of 25-hydroxyvitamin D3, retinol, and retinolbinding protein. Am J Clin Nutr 44:678-682

Böhlandt A, Schierl R, Diemer J, Koch C, Bolte G, Kiranoglu M et al (2012) High concentrations of cadmium, cerium and lanthanum in indoor air due to environmental tobacco smoke. Sci Total Environ 414:738-741

Bolte G, Heitmann D, Kiranoglu M, Schierl R, Diemer J, Koerner W et al (2008) Exposure to environmental tobacco smoke in German restaurants, pubs and discotheques. J Expo Sci Environ Epidemiol 18(3):262-271

Brittain HG, Richardson FS, Martin RB (1976) Terbium(III) emission as a probe of calcium(II) binding sites in proteins. J Am Chem Soc 98:8255-8260

Brown CJ, Chenery SR, Smith B, Mason C, Tomkins A, Roberts GJ et al (2004) Environmental influences on the trace element content of teeth-Implications for disease and nutritional status. Arch Oral Biol 49(9):705-717

Cao X, Chen Y, Wang X, Deng X (2001) Effects of redox potential and $\mathrm{pH}$ value on the release of rare earth elements from soil. Chemosphere 44(4):655-661

Carrillo-López N, Fernández-Martín JL, Alvarez-Hernández D, González-Suárez I, Castro-Santos P, Román-García $\mathrm{P}$ et al (2010) Lanthanum activates calcium-sensing receptor and enhances sensitivity to calcium. Nephrol Dial Transplant 25(9):2930-2937

Chen ZY, Liu Y, Wang YX (2000) Study on distributions and accumulations of rare earth element cerium (141Ce) in mice. J Nanjing Agric Univ 23:101-103

Darszon A, Nishigaki T, Wood C, Treviño CL, Felix R, Beltrán C (2005) Calcium channels calcium fluctuation in sperm motility. Physiol Int Rev Cytol 243:79-172

Davidson M, Wilce P, Shanley B (1990) Ethanol and synaptosomal calcium homeostasis. Biochem Pharmacol 39(8): $1283-1288$

dos Remedios CG (1981) Lanthanide ion probes of calcium-binding sites on cellular membranes. Cell Calcium 2:29-51

Eisele GR, Mraz FR, Woody MC (1980) Gastrointestinal uptake and $144 \mathrm{Ce}$ in the neonatal mouse, rat and pig. Health Phys 39: $185-192$

Fakih H, MacLusky N, DeCherney A, Wallimann T, Huszar G (1986) Enhancement of human sperm motility and velocity in vitro: Effects of calcium and creatine phosphate. Fertil Steril 46:938-944

Feng L, He X, Xiao H, Li Z, Li F, Liu N et al (2007) Ytterbium and trace element distribution in brain and organic tissues of offspring rats after prenatal and postnatal exposure to ytterbium. Biol Trace Elem Res 117:89-104 
Feng L, Xiao H, He X, Li Z, Li F, Liu N et al (2006) Neurotoxicological consequence of long-term exposure to lanthanum. Toxicol Lett 165:112-120

Ford C, Wells FE, Rogers JN (1995) Assessment of iron status in association with excess alcohol consumption. Ann Clin Biochem 32:527-531

Forsander OA (1998) Dietary influences on alcohol intake: A review. J Stud Alcohol 9(1):26-31

Fraser LR (1987) Minimum and maximum extracellular $\mathrm{Ca}^{2+}$ requirements during mouse sperm capacitation and fertilization in vitro. J Reprod Fertil 81:77-89

Fromme H, Dietrich S, Heitmann D, Dressel H, Diemer J, Schulz T et al (2009) Indoor air contamination during a waterpipe (narghile) smoking session. Food Chem Toxicol 47(7):1636-1641

Gerhardsson L, Brune D, Nordberg IG, Wester PO (1985) Protective effect of selenium on lung cancer in smelter Workers. Br J Ind Med 42:617-626

Gerhardsson L, Nordberg GF (1993) Lung cancer in smelter workers-Interactions of metals as indicated by tissue levels. Scand J Work Environ Health 19(Suppl 1):90-94

Gómez-Aracena J, Riemersma RA, Gutiérrez-Bedmar M, Bode P, Kark JD, Garcia-Rodríguez A et al (2006) Toenail cerium levels and risk of a first acute myocardial infarction: The EURAMIC and heavy metals study. Chemosphere 64(1):112-120

He ML, Rambeck WA (2000) Rare earth elements-A new generation of growth promoters for pigs? Arch Tierernähr 53:323-334

He ML, Wehr U, Rambeck WA (2010) Effect of low doses of dietary rare earth elements on growth performance of broilers. J Anim Physiol Anim Nutr (Berl) 94:86-92

He X, Zhang Z, Zhang H, Zhao Y, Chai Z (2008) Neurotoxicological evaluation of long-term lanthanum chloride exposure in rats. Toxicol Sci 103:354-361

Heitland P, Köster HD (2006) Biomonitoring of 37 trace elements in blood samples from inhabitants of northern Germany by ICPMS. J Trace Elem Med Biol 20(4):253-262

Hong CY, Chiang BN, Turner P (1984) Calcium ion is the key regulator of human sperm function. Lancet 2:1449-1451

Huang P, Li J, Zhang S, Chen C, Han Y, Liu N, Xiao Y et al (2011) Effects of lanthanum, cerium, and neodymium on the nuclei and mitochondria of hepatocytes: Accumulation and oxidative damage. Environ Toxicol Pharmacol 31:25-32

International Agency for Research on Cancer (2004) Tobacco smoke and involuntary smoking. IARC monographs on the evaluation of carcinogenic risks to humans, vol 83. IARC Press, Lyon

Kam SC, Chae MR, Kim JY, Choo SH, Han DH, Lee SW (2010) Effects of ethanol on the tonicity of corporal tissue and the intracellular $\mathrm{Ca}^{2+}$ concentration of human corporal smooth muscle cells. Asian J Androl 12(6):890-898

Kawagoe M, Ishikawa K, Wang SC, Yoshikawa K, Arany S, Zhou XP et al (2008) Acute effects on the lung and the liver of oral administration of cerium chloride on adult, neonatal and fetal mice. J Trace Elem Med Biol 22:59-65

Kobayashi K, Shida R, Hasegawa T, Satoh M, Seko Y, Tohyama C et al (2005) Induction of hepatic metallothionein by trivalent cerium: role of interleukin 6. Biol Pharm Bull 28:1859-1863

Konda Y, Sakamoto C, Nishisaki H, Nakano O, Matozaki T, Nagao M, Matsuda K et al (1991) Ethanol stimulates pepsinogen release by opening a $\mathrm{Ca} 2+$ channel of guinea pig gastric chief cells. Gastroenterology 100(1):17-24

Korsvik C, Patil S, Seal S, Self WT (2007) Superoxide dismutase mimetic properties exhibited by vacancy engineered ceria nanoparticles. Chem Commun (Camb) 14(10):1056-1058

Labib M, Ranganath L, Southgate J, Gama R, Teale D, Marks V (1989) Acute effect of ethanol intake on plasma osteocalcin concentration. Ann Clin Biochem 26:563-564
Lansman JB (1990) Blockade of current through single calcium channels by trivalent lanthanide cations. Effect of ionic radius on the rates of ion entry and exit. J Gen Physiol 95:679-696

Lee WM, Tsang AY, Wong PY (1981) Effects of divalent and lanthanide ions on motility initiation in rat caudal epididymal spermatozoa. Br J Pharmacol 73(3):633-638

Lindemann CB, Goltz JS, Kanous KS (1987) Regulation of activation state and flagellar wave form in epididymal rat sperm: evidence for the involvement of both $\mathrm{Ca}^{2+}$ and cAMP. Cell Motil Cytoskelet 8:324-332

Logoglu G, Kendirci A, Özgűnen T (1997) The role of seminal calcium in male infertility. J Isla Acad Sci 10(1):25-27

Lusier M, Vodez JF, Donath A, Courvoisier B, Garcia B (1977) 25-hydroxy vitamin D deficiency with reduction of intestinal calcium absorption and bone density in chronic alcoholism. Schweiz Med Wochenschr 107:1529-1533

Martin RB, Richardson F (1979) Lanthanides as probes for calcium in biological systems. Q Rev Biophys 12:181-209

Marzec-Wróblewska U, Kamiński P, Łakota P, Szymański M, Wasilow K, Ludwikowski G et al (2011) Zinc and iron concentration and SOD activity in human semen and seminal plasma. Biol Trace Elem Res 143:167-177

Mikkelson RB (1976) Lanthanides as calcium probes in biological membranes. In: Chapman D, Wallach DFH (eds) Biomembranes. Academic Press, New York

Minoia C, Sabbioni E, Apostoli P, Pietra R, Pozzoli L, Gallorini M et al (1990) Trace element reference values in tissues from inhabitants of the European Community. I. A study of 46 elements in urine blood and serum of Italian subjects. Sci Total Environ 95:89-105

Monafo WW, Tandon SN, Ayvazian VH, Tuchschmidt J, Skinner AM, Deitz F (1976) Cerium nitrate: a new topical antiseptic for extensive burns. Surgery 80:465-473

Morita H, Kita T, Umeno M, Morita M, Yoshinaga J, Okamoto K (1994) Analysis of serum elements and the contaminations from devices used for serum preparation by inductively coupled plasma mass spectrometry. Sci Total Environ 151:9-17

Morton B, Harrigan-Lum J, Albagli L, Jooss T (1974) The activation of motility in quiescent hamster sperm from the epididymis by calcium and cyclic nucleotides. Biochem Biophys Res Commun 56:372-379

Nakamura Y, Tumura Y, Tonogai Y, Shibata T, Ito Y (1997) Differences in behavior among the chlorides of seven rare earth elements administered intravenously to rats. Fundam Appl Toxicol 37:106-116

Nishimura K (1993) Effects of calcium ions on the malate-aspartate shuttle in slow-cooled boar spermatozoa. Biol Reprod 49(3):537-543

Oral R, Bustamante P, Warnau M, D'Ambra A, Guida M, Pagano G (2010) Cytogenetic and developmental toxicity of cerium and lanthanum to sea urchin embryos. Chemosphere 81:194-198

Palasz A, Czekaj P (2000) Toxicological and cytophysiological aspects of lanthanides action. Acta Biochim Polonica 47:107-1114

Pandy VK, Parmeshwaran M, Soman SD (1983) Concentrations of morphologically normal, motile spermatozoa: $\mathrm{Mg}, \mathrm{Ca}$ and $\mathrm{Zn}$ in the semen of infertile men. Sci Total Environ 27:49-52

Peng RL, Pan XC, Xie Q (2003) Relationship of the hair content of rare earth elements in young children aged 0 to 3 years to that in their mothers living in a rare earth mining area of Jiangxi. Zhonghua Yu Fang Yi Xue Za Zhi 37(1):20-22

Porru S, Placidi D, Quarta C, Sabbioni E, Pietra R, Fortaner S (2001) The potential role of rare earths in the pathogenesis of interstitial lung disease: A case report of movie projectionist as investigated by neutron activation analysis. J Trace Elem Med Biol 14:232-236

Reeves JP, Condrescu M (2003) Lanthanum is transported by the sodium/calcium exchanger and regulates its activity. Am J Physiol Cell Physiol 285(4):763-770 
Rodushkin I, Ödman F, Branth S (1999) Multielement analysis of whole blood by high resolution inductively coupled plasma mass spectrometry. Fresenius J Anal Chem 364:338-346

Rylander R, Megevand Y, Lasserre B, Amstutz W, Granbom S (2001) Moderate alcohol consumption and urinary excretion of magnesium and calcium. Scand J Clin Lab Invest 61:401-405

Rzigalinski BA, Meehan K, Davis RM, Xu Y, Miles WC, Cohen CA (2006) Radical nanomedicine. Nanomedicine (Lond) 1:399-412

Saling PM (1982) Development of the ability to bind to zonae pellucidae during epididymal maturation: Reversible immobilization of mouse-spermatozoa by lanthanum. Biol Reprod 26(3):429-436

Santori C, Ceccanti M, Diacinti D, Attilia ML, Toppo L, D'Erasmo E et al (2008) Skeletal turnover, bone mineral density, and fractures in male chronic abusers of alcohol. J Endocrinol Invest 31:321-326

Slezakova K, Pereira MC, Alvim-Ferraz MC (2009) Influence of tobacco smoke on the elemental composition of indoor particles of different sizes. Atmos Environ 43(3):486-493

Sørensen MB, Bergdahl IA, Hjøllund NH, Bonde JP, Stoltenberg M, Ernst E (1999) Zinc, magnesium and calcium in human seminal fluid: relations to other semen parameters and fertility. Mol Hum Reprod 5(4):331-337

Tash JS, Mean AR (1982) Regulation of protein phosphorylation and motility of sperm by cyclic adenosine monophosphate and calcium. Biol Reprod 26:745-763

United States Department of Health and Human Services (2006) The health consequences of involuntary exposure to tobacco smoke: A report of the surgeon general. US Department of Health and Human Services, Centers for Disease Control and Prevention, Coordination Center for Health Promotion, National Center for Chronic Disease Prevention and Health Promotion, Office on Smoking and Health, Atlanta

Umeyama T, Ishikawa H, Takeshima H, Yoshii S, Koiso K (1986) A comparative study of seminal trace elements in fertile and infertile men. Fertil Steril 46:494-499

Valsa J, Skandhan KP, Khan PS, Sumangala B, Gondalia M (2012) Split ejaculation study: Semen parameters and calcium and magnesium in seminal plasma. Cent Eur J Urol 65(4):216-218

Vayena E, Rowe PJ, Griffin PD (2002) Current practices and controversies in assisted reproduction: Report of a WHO meeting, Medical, ethical and social aspects of assisted reproduction. World Health Organization, Geneva

Wang CL, Aquaron RR, Leavis PC, Gergely J (1982) Metal-binding properties of calmodulin. Eur J Biochem 124(1):7-12

World Health Organization (2010) WHO laboratory manual for examination and processing of human semen, 5th edn. WHO, Geneva

Wong WY, Flik G, Groenen PMW, Swinkels DW, Thomas CMG, Copius-Peereboom JHJ et al (2001) The impact of calcium, magnesium, zinc, and copper in blood and seminal plasma on semen parameters in men. Reprod Toxicol 15:131-136

Xiaofei L, Zhibiao C, Zhiqiang C, Yonghe Z (2013) A human health risk assessment of rare earth elements in soil and vegetables from a mining area in Fujian Province, Southeast China. Chemosphere 93:1240-1246

Yamada S, Yoshida H, Taniguchi M, Tanaka S, Eriguchi M, Nakano $T$ et al (2012) Effectiveness of lanthanum carbonate treatment used in combination with other phosphate binders in peritoneal dialysis patients. Intern Med 51(16):2097-2104

Yanagimachi R, Usui N (1974) Calcium dependence of the acrosome reaction and activation of guinea pig spermatozoa. Exp Cell Res 89:161-174

Yanagimachi R (1981) Mechanisms of fertilization in mammals. In: Mastroianni L, Biggers JD (eds) Fertilization and embryonic development in vitro. Plenum, New York, pp 88-182

Yang J, Liu Q, Zhang L, Wu S, Qi M, Lu S et al (2009) Lanthanum chloride impairs memory, decreases pCaMK IV, pMAPK and pCREB expression of hippocampus in rats. Toxicol Lett 190:208-214

Yu L, Dai Y, Yuan Z, Li J (2007) Effects of rare earth elements on telomerase activity and apoptosis of human peripheral blood mononuclear cells. Biol Trace Elem Res 116:53-59

Zegers-Hochschild F, Adamson GD, de Mouzon J, Ishihara O, Mansour R, Nygren K et al (2009) International Committee for Monitoring Assisted Reproductive Technology (ICMART) and the World Health Organization (WHO) revised glossary of ART terminology 2009. Fertil Steril 92(5):1520-1524

Zhang S, Shan XQ (2001) Speciation of rare earth elements in soil and accumulation by wheat with rare earth fertilizer application. Environ Pollut 112(3):395-405 